\title{
The Enlightenment of Taizhou Glass Engraving Art on the Visual Arts of Modern Poster Design
}

\author{
Huiying $\mathrm{Lu}^{1, *}$ \\ ${ }^{1}$ Fuzhou University, Fuzhou, Fujian, China \\ *Corresponding author. Email: 524188588@qq.com

\begin{abstract}
The visual art presentation of modern poster design is impacted and influenced by various cultures, extending more and more visual expression styles, and each style performs its own unique artistic charm. Among them, transparent, reflective, light and shadow and other highly visual and novel poster styles emerge one after another, which are loved by the public. Glass is concerned by people because of its unique material and aesthetic characteristics. From the perspective of glass engraving art, this paper analyzes the beauty of glass from the perspectives of material beauty, decorative beauty, functional beauty and artistic conception beauty, and constructs the relationship between glass and poster design of glass style, so as to provide ideas for the visual art of modern poster design. The seemingly cold and hard glass engraving art has richer expression in the design field, which makes the excellent traditional culture glow with new vitality in the contemporary era.
\end{abstract}

Keywords: Glass engraving, Poster visual art, Design style.

\section{INTRODUCTION}

Glass engraving art is an important and unique category of modern art design. Its unique material characteristics, design elements, engraving techniques, extensive application fields and artistic inheritance value make it have a unique position in the field of art and design and have a positive impact on many industries. Among them, the diversity of visual styles and themes of poster design make poster design highly inclusive. More poster design also requires its visual effects to constantly get rid of the stale and bring forth the fresh and keep up with the pace of the times. Viewing the visual art of modern poster design from the perspective of Taizhou glass engraving art, it is not difficult to find that the traditional glass engraving art language is closely related to the aesthetic trend of visual elements of poster design. It is necessary to re-examine the power of excellent traditional culture and make the culture shining in history have broader development possibilities in modern times.

\section{TAIZHOU GLASS ENGRAVING ART AND VISUAL ART OF MODERN POSTER}

\subsection{Taizhou Glass Engraving and Wu Zixiong's Glass Engraving Art}

Ancient Egyptians were the first to make glass, which has a history of more than four thousand years and is used for the decoration of doors and windows. Chinese ancestors also made colorless glass at the end of the Shang Dynasty or the beginning of the Western Zhou Dynasty, which is transparent glass. It can be seen that glass has a long history. In China, the development of glass artwork has been precipitated and tested for a long time.

Taizhou glass engraving skill is a local traditional handicraft skill in Zhejiang Province. It originated in the late Qing Dynasty and became popular in the process of development and reform. And it has developed a school of its own in the national arts and crafts. There are rich themes, ranging from birds and animals, landscapes, figures and portraits to insects, flowers and plants. The glass engraving art adopts a very rich and special 
method of cutting to show the inherent beauty of materials and display the exquisite glass modeling language. Therefore, its cultural and artistic inheritance is very commendable. In Taizhou, $\mathrm{Wu}$ Zixiong is a master of glass engraving art, and is renowned in China and foreign countries. With consummate engraving craft, he has produced many glass artworks with rich connotation and technological research value. "Wu Zixiong glass art museum" funded by Wu Zixiong ("Figure 1") is the first glass engraving art museum in China. When people enter the museum, they would go into the world of glass art. People can appreciate the unique charm of glass art from strong artistic atmosphere of glass engraving and wonderful glass engraving works in Taizhou.

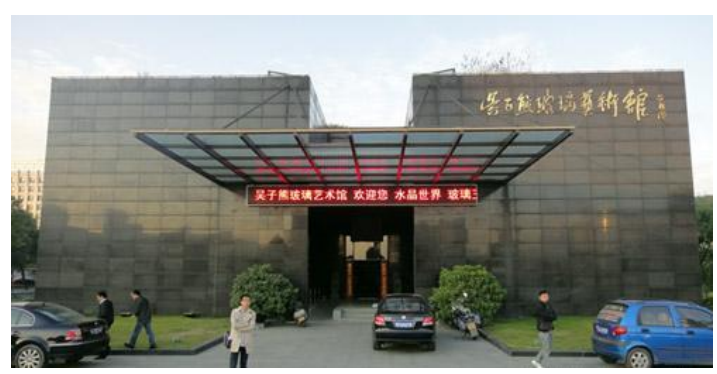

Figure 1 Taizhou Wuzixiong Glass Art Museum (source: Internet).

\subsection{The Relationship Between Glass Engraving Art and Visual Art of Modern Poster}

In people's impression, glass engraving art is a traditional handicraft. Carvers use various engraving techniques to create three-dimensional or flat works of art on glass. People feel the ingenuity of the creator when appreciating the work. The functions of being used, display, decoration and collection will be realized. With the launch of the industrial revolution and the popularization of mechanization, more and more machines have replaced handwork. Many mass-produced glass products make more and more people ignore the original temperature sense of glass artworks. In people's impression, glass is cold. And people gradually forget the craftsmanship and inheritance behind glass art. However, the story and temperature behind the glass engraving art need to be explored, because design is warm.

Glass engraving art and visual art of modern poster also need the integration of more forms and cultures, so as to convey the creative design intention and information of a poster. Against the background of the great prosperity of Chinese culture, glass art and cultural industry are closely integrated. [1] In recent years, the popular trend of poster design has gradually changed from being flat to three-dimensional, deriving rich material effects such as transparency, laser, light and shadow, gradual change, and these changes are closely related to glass engraving art. From raw material to engraving and polishing and then to display of artistic work of glass, different works will present different visual art styles due to different cutting skills, morphologic expression, shadow and display scene, such as the light refraction and change of the colors. The beauty of different visual arts gives more inspiration to visual art of modern poster design.

\section{THE ENLIGHTENMENT OF ARTISTIC CHARACTERISTICS OF TAIZHOU GLASS ENGRAVING ART ON THE VISUAL AESTHETIC CHARACTERISTICS OF MODERN POSTERS}

\subsection{The Beauty of Glittering and Translucent Material}

The glass engraving art gives many new inspirations to the visual effect of contemporary posters. First of all, it is necessary to make the innovation from the material. Taking glass engraving art in Taizhou as an example, it can be found from some works ("Figure 2") that glass materials are transparent and reflective, which are the characteristics of light elements reflected in glass. In art design, the combination of glass materials and light elements can make glass art perform profound artistic charm. [2] The transmission of light is one of the biggest characteristics of glass material, which is different from wood, iron, plastic and other materials. At the same time, transmission of light makes works have more mysterious and vivid colors. When people appreciate glass art, they cannot help but sign with emotion that light stays in glass works and links different structures such as positive and negative shapes, virtual and real space, and superposition order and so on, performing rich and changing effects. [3] The reflection of light makes glass works more flexible, giving people richer visual aesthetic experience. Modern poster design also began to refine the material characteristics of glass for creation. 3D modeling software is used to 
achieve the three-dimensional, and relevant materials and lights are given to create the aesthetic feeling of glass material. Through these material characteristics, the modern, scientific and trendy sense of the poster is displayed, so that the poster has a more novel performance effect ("Figure 3").

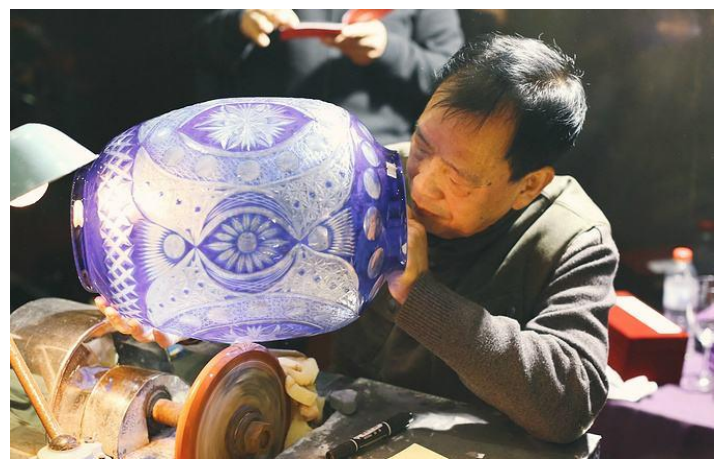

Figure $2 \mathrm{Wu}$ Zixiong make the artwork of glass engraving (source: Internet).

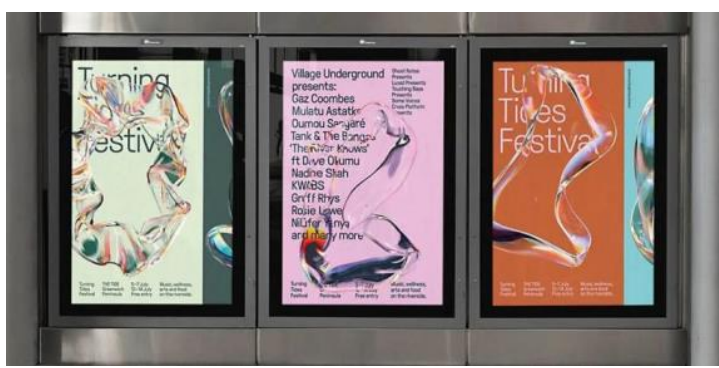

Figure 3 Visual style of modern poster design with transparent glass texture (source: Internet)

\subsection{Exquisite and Transparent Decorative Beauty}

Taizhou glass engraving art works use a variety of carving techniques. Combined with the needs of different works, integration of design intentions, glass engraving art works show many decorative design elements. From the perspective of flat glass engraving art work ("Figure 4"), its decorative beauty is reflected in composition skills, element planning, design creativity, carving techniques. Carvers present the effect on the glass plane through the design of all aspects, including figures, animals, flowers and birds, etc., and the decorative beauty of Taizhou glass engraving can be shown mainly through the realistic and delicate processing. From the perspective of three-dimensional glass engraving art works, more artistic processing methods, such as flat glass, hot bending glass, three-dimensional glass, are used to realize the purpose of multi-form glass, so that threedimensional works can be better performed according to the intention of the designers. The decorative beauty of three-dimensional glass engraving works tests the designer's manufacturing level, and its decorative sense reflects more diversified techniques, such as the depiction of the hierarchical sense of objects, the overlapping effect produced by the interlace of three-dimensional effects, etc. ("Figure 5", "Figure 6"). Different decoration method of different types of glass engraving works give the same way of thinking to modern graphic poster. For the graphic works, it is required to consider two-dimensional and threedimensional effect in two-dimensional images. Under the trend of turning from plane to threedimensional design, it is necessary to combine glass engraving decoration skills and three-dimensional thinking and skilfully use exquisite decorative beauty. Finally, it is possible to explore a distinctive visual style of modern poster design in the original poster design.

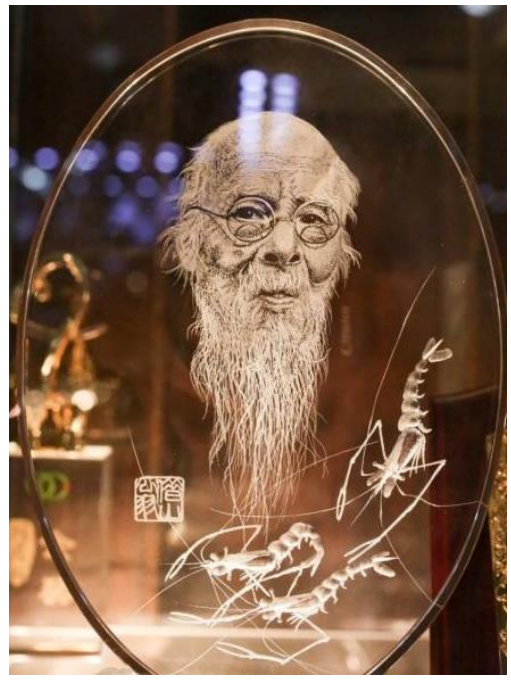

Figure $4 \mathrm{Wu}$ Zixiong's flat glass engraving art works (source: Internet).

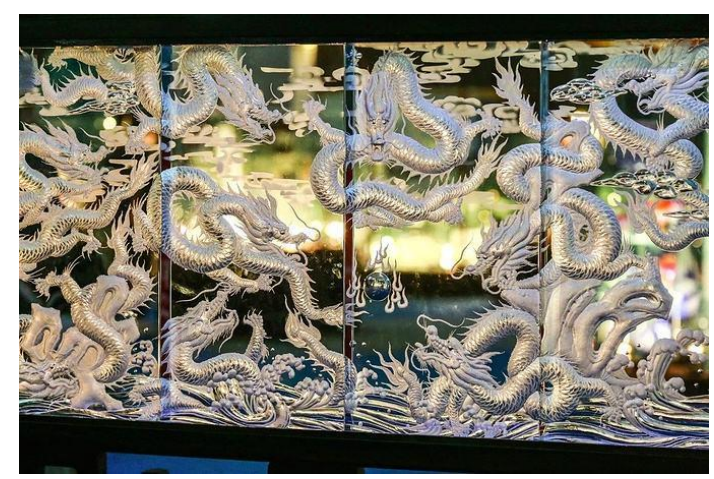

Figure $5 \mathrm{Wu}$ Zixiong's three-dimensional glass engraving art works (source: Internet). 


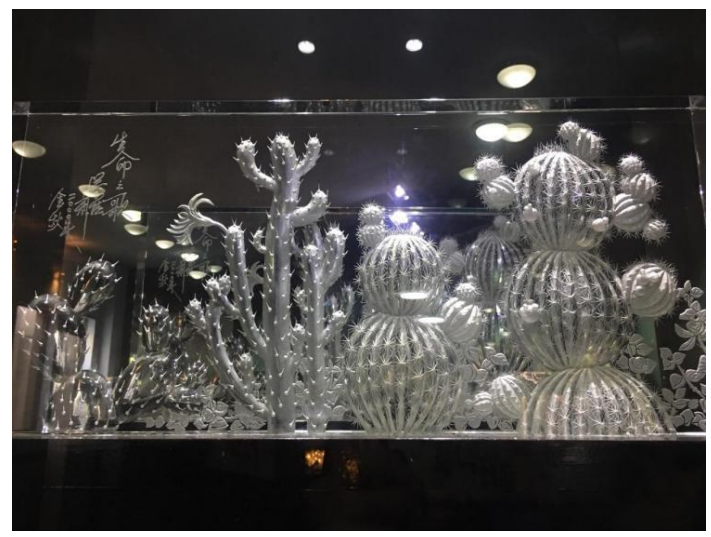

Figure $6 \mathrm{Wu}$ Zixiong's three-dimensional glass engraving art works (source: Internet).

\subsection{Rich and Practical Functional Beauty}

Different types of glass engraving works play different roles in life and show different functional beauty. In addition to many glass works being collected, glass works have been used in different fields. In Taizhou, some glass products are used for daily life, such as red wine glass engravings, clock engravings of antique style, etc., with patterns biased towards life, which not only meet people's aesthetic needs but also conform to the style of life, adding quality sense to people's life. For example, in the field of architecture, Taizhou people also use some glass engravings. The function of glass is reflected in providing people with better living experience, helping lighting, adding a sense of design and so on. Even through the refraction of light, glass can produce a certain virtual fantasy effect on the basis of objective reality. [4] Glass has its own role and mission in different use scenarios, realizing the functions of aesthetics, entertainment, practicality, publicity, affection, memorial, collection and so on. The design of posters requires designers to accurately position the audience according to the poster design theme, plan the expected information and benefits, and design works with ingenious conception, novel vision and in-place information. If the visual style of poster design is determined as the visual style of glass art, it is necessary to select a specific glass decoration pattern or style according to the specific theme, create a specific atmosphere through different glass forms and scene lights, and form the style of the theme poster, so as to maximize the publicity benefits of the poster and realize the functionality of the poster.

\subsection{The Artistic Conception Beauty of Developing Association}

Whether it is Taizhou glass engraving art or modern poster design visual art, one of the general characters is that they have the artistic conception beauty that can make people unconsciously start to associate. Through the performance of the external model of glass engraving, it allows people to experience the intrinsic beauty, and find the story behind the works after feeling the mystery of glass works. There are a thousand Hamlets for a thousand readers. Different understandings of art works make the work have more profound connotation. As shown in "Figure 7", behind this big tree, different people have different understandings, such as life, hope, and accumulation and power of time.

The similarity of poster artistic conception beauty is reflected in the infinite design association outside the limited design elements, that is, after the poster works accurately convey the design intention, the audience carry out rich association and imagination. At this time, the role of poster has been brought into better play. Nowadays, with the development of multimedia and the progress of technology, poster design has more carrier expression. For example, the emergence of dynamic posters makes the works more directional to guide people into the world of artistic conception beauty. For example, the poster of graduation design exhibition of Guangzhou Academy of Fine Arts ("Figure 8") uses the dynamic and static combination of glass laser to give the posters more possibilities of extension and change. Therefore, the publicity of the posters can be more deeply accepted and remembered by people, highlighting the artistic conception beauty, advancement and fashion of modern excellent posters.

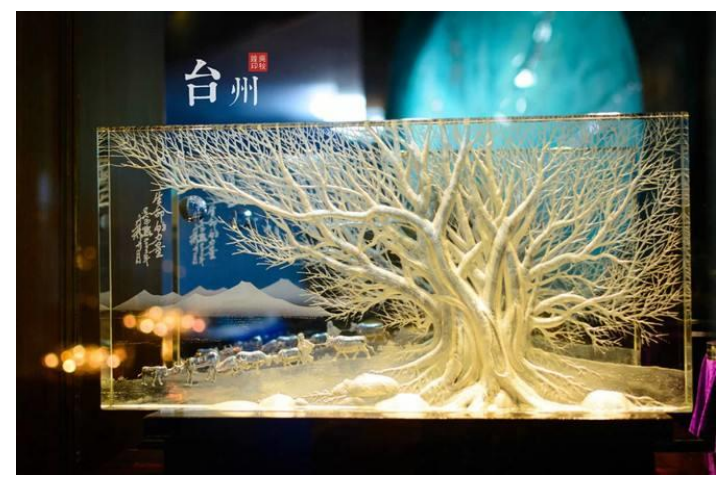

Figure $7 \mathrm{Wu}$ Zixiong's glass engraving art works (source: Internet). 


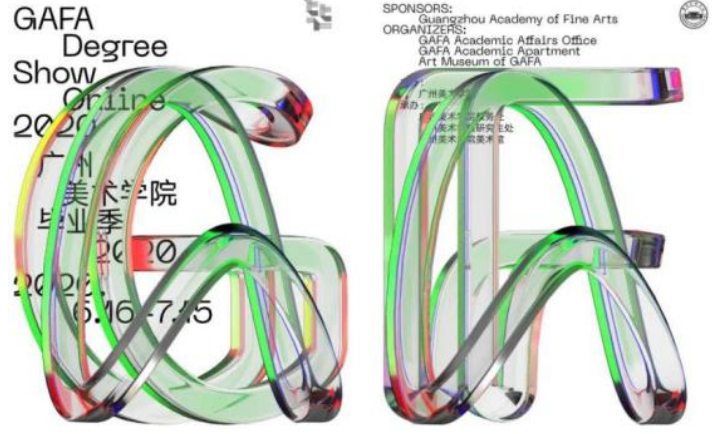

Figure 8 Poster of graduation design exhibition of Guangzhou Academy of Fine Arts (source: Internet).

\section{TAIZHOU GLASS ENGRAVING ART PROMOTES THE INNOVATION OF VISUAL STYLE OF MODERN POSTERS}

\subsection{Seeking Modern Beauty in Excellent Traditional Culture}

Chinese culture has a long history, and many excellent traditional cultures that were once ignored by us are our precious wealth. Taizhou glass engraving art gives enlightenment to the new expression methods of modern poster visual style, which makes everyone pay more attention to finding modern beauty in traditional art and culture. It not only makes the excellent traditional culture of Taizhou glass engraving get innovative excavation and dissemination in the new era, but also makes the visual style of modern poster design show new artistic beauty with the addition of traditional culture. From Taizhou glass engraving art, people can see the unique and modern material beauty of glass, find exquisite and shocking decorative patterns, understand the different functions carried by different works, and realized the wonderful and valuable artistic conception beauty of works. These are the entry points and key points that can be explored continuously and inspire the design of modern poster style. Taizhou glass engravings can also be used in more fields to achieve a win-win situation.

\subsection{Excellent Traditional Culture Guides the Future Fashion Style}

Glass engraving art can give creators more inspiration and provide creators with more novel and unique design ideas. Similarly, in the context of cultural self-confidence, China's rich and dazzling traditional excellent culture and civilization is a huge wealth. These cultures not only reflect local characteristics, but also have national genes, which are worthy of learning and inheritance. In the process of inheriting and carrying forward the excellent Chinese traditional culture, it is required to focus on the creative transformation and innovative development of culture, so as to make it more in line with the needs of contemporary fashion or the people, make cultural innovation with temperature, innovation and inheritance significance. The culture can live better and go on, and the excellent traditional culture guides the direction of future fashion style.

\section{CONCLUSION}

With the joint efforts of intangible cultural heritage inheritors and glass artists, Taizhou glass engraving art has made different degrees of exploration and achievements in manufacturing type, engraving technology, light and shadow, color and so on. Glass engraving art has established a connection with the visual art of modern poster design with its unique material characteristics, aesthetic characteristics and spiritual symbols, provides more expression ideas and methods for the style of modern poster design, and constantly enriches the visual art system of poster design. The exploration of excellent traditional culture will never stop. It is necessary to adhere to cultural selfconfidence, find potential cultural flash points with a developing and insightful vision, and let the excellent traditional culture pass on from generation to generation and burst out more brilliance.

\section{AUTHORS' CONTRIBUTIONS}

This paper is independently completed by Huiying Lu.

\section{REFERENCES}

[1] Han Xi. Inheritance of glassware - from the perspective of cultural cognition [J]. Art Education Research, 2019(01): 42-43. (in Chinese)

[2] Wang Yifeng. On the diversified development of the language of glass art from the perspective of the development of modern art [J]. Panorama of Chinese Nationalities, 2017(10):113-114. (in Chinese) 
[3] Sun Zhihao. The Story Behind the Light The Aesthetic Evolution of Glass Art from the Postmodern Perspective [J]. Journal of Nanjing Arts Institute (Fine Arts \& Design), 2019(03):144-146. (in Chinese)

[4] Guo Qimei, Liu Peng. Analysis of the aesthetic application of glass art in space design [J]. Art and Literature for the Masses, 2014(03):66. (in Chinese)

[5] Zhang Yunyun. On the importance of light and shadow in the aesthetic empathy of glass art [J]. Shanghai Arts and Crafts, 2015(04):8890. (in Chinese)

[6] Su Hang. The aesthetic trend of contemporary glass art $[\mathrm{J}]$. Shanghai Arts and Crafts, 2018(02):98-100. (in Chinese)

[7] Wang Yundian. On the Expression of "Artistic Conception" in Glass Art [D]. Jilin University of the Arts, 2018. (in Chinese)

[8] Qi Jing. The aesthetic value and application of the art form of traditional glass mosaic painting in modern decorative painting [D]. Sichuan Fine Arts Institute, 2018. (in Chinese) 